\title{
НАУКОВО-ПСИХОЛОГІЧНИЙ СУПРОВІД В ОСВІТІ ДІТЕЙ З ОСОБЛИВИМИ ПОТРЕБАМИ
}

\author{
Наукова доповід ь на загальних зборах НАПН України 17 грудня 2019 р. \\ https://doi.org/10.37472/2707-305X-2019-1-1-1-5
}

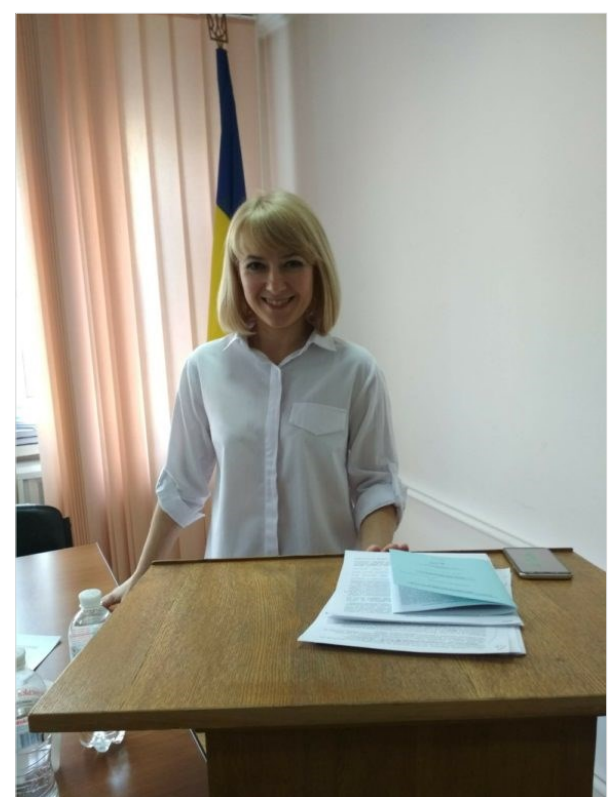

ПРОХОРЕНКО Леся Іванівна

доктор психологічних наук, заступник директора з науковоекспериментальної роботи Iнституту спеціальної педагогіки і психології імені Миколи Ярмаченка Начіональної академії педагогічних наук України, м. Київ, Україна

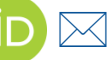

Анотація. Автором окреслено важливі питання освіти дітей з особливими освітніми потребами, зокрема зосереджено увагу на технологіях соціального, психологічного та педагогічного супроводів дітей з особливими потребами, в яких першочерговим є виявлення особливостей особистісного розвитку дитини та ї̈ соціального становлення в умовах школи.

обгрунтовано, що зміна стереотипів у розумінні проблем навчання і виховання дітей з особливими потребами має базуватися на нових підходах, які кониентруються не на порушеннях особисmості, а містять у підгрунті особистісну орієнтацію, освітні компетентності, створення належних умов щодо рівних можливостей здобуття освіти для дітей та молоді, варіативність навчання відповідно до здібностей та індивідуальних можливостей таких осіб ma iн.

З урахуванням основних тенденцій щодо змін у системі освіти дітей з особливими освітніми потребами окреслено напрями діяльності, які потребують підвищеної уваги, провідними з яких є: науково-методичний супровід освіти осіб з особливими потребами та психолого-педагогічний супровід таких осіб у прочесі навчання, соціалізації, життєдіяльності.

Ключові слова: науково-психологічний супровід; освіта dimeй з особливими потребами; раннє втручання; інклюзивне навчання.

Залучення осіб з особливими потребами до загальноосвітнього простору України $є$ одним із пріоритетних напрямів державної освітньої політики, яка гарантує їм право на освіту й забезпечення рівних можливостей у всіх сферах суспільного життя, що окреслено у низці документів: Державній національній програмі «Освіта» (Україна XXI ст.), Національній доктрині розвитку освіти, Законі України «Про освіту», постановах Кабінету Міністрів України «Про затвердження Положення про інклюзивно-ресурсний центр», "Деякі питання створення ресурсних центрів підтримки інклюзивної освіти та інклюзивно-ресурсних центрів», наказах Міністерства освіти і науки України «Про затвердження концепції розвитку інклюзивного навчання», «Про затвердження Примірного положення про команду психологопедагогічного супроводу дитини з особливими освітніми потребами в закладі загальної середньої та дошкільної освіти» та ін.

Ефективним вирішенням питань освіти осіб з особливими потребами є програма державного сприяння розвитку інклюзивного навчання, що було закріплено новим Законом України «Про освіту». Такий підхід до навчання «особливих» дітей зумовлений різними чинниками, зокрема тим, що надання освітніх послуг таким дітям в закладах інтернатного типу певною 
мірою призводить до зниження у них соціальної компетентності та дезадаптації в соціумі.

у загальному баченні інклюзивна парадигма передбачає надання підтримки особам з особливими потребами, яка може впроваджуватися у різних формах супроводу: технічному (забезпечення відповідного обладнання, завдяки чому людина з обмеженими можливостями здатна жити більш незалежним життям), психологопедагогічному (освітні послуги, психологічна допомога, підтримка, консультації в освітньому й соціальному середовищі), соціальному (соціальна адаптація осіб з особливими потребами у тому оточенні, в якому вони перебувають: родині, школі, трудовому колективі та ін.), науково-психологічному (розроблення наукового, навчально-методичного практично-спрямованого забезпечення освіти, життєдіяльності, соціалізації осіб з особливими потребами на основі законодавчих нормативно-правових актів) та інших.

Посилено увагу до проблеми психологічного і соціального супроводів учасників навчальновиховного процесу в умовах інклюзивного навчання, що передбачає пристосування освітнього середовища до потреб дитини з урахуванням ії особливостей і можливостей та забезпечення соціальних попитів. Зокрема це: соціальнопсихологічна діагностика, моніторинг особистісного розвитку і соціальної ситуації розвитку осіб з особливими потребами, прогнозування змін освітньої ситуації та визначення ії основних тенденцій; проектування і соціально-психологічна корекція особистісного розвитку дітей у навчальновиховному процесі; соціально-психологічна і педагогічна реабілітація дітей із особливими потребами юнацького віку; консультативно-методична допомога всім учасникам навчально-виховного процесу.

Значної ваги у цьому контексті набуває науково-психологічний супровід з позицій психологічних, педагогічних, організаційно-методичних вимог щодо забезпечення якісної освіти дітей з особливими освітніми потребами, що передбачає вивчення особистісного потенціалу дитини, а саме: співвідношення рівня інтелектуального розвитку, когнітивної сфери і вікової норми, індивідуально-типологічних особливостей, виявлення труднощів у навчанні, спілкуванні та соціальній адаптації, визначення резервів розвитку.

Насамперед, пристосування освітнього середовища до потреб дитини з особливими потребами передбачає і потребує впровадження нових технологій супроводу, найпоширенішими серед яких є: технологія виявлення особливостей розвитку дитини, визначення ії потреб для подальшого розроблення корекційно-розвивальної стратегії; технологія психопрофілактики як створення відповідних умов в закладі освіти з опорою на середовищні ресурси; технологія системної корекційно-розвивальної роботи 3 дитиною 3 опорою на базові структури психічної організації; технологія командної взаємодії учасників групи супроводу, що визначає пріоритети, стратегію супроводу та розробляє індивідуальну програму розвитку дитини; технологія самооцінки професійного розвитку педагогів та інші.

3 огляду на важливість цієї проблеми в навчанні дітей з особливими потребами хотілося 6 у стислій формі означити, що вже зроблено, й окреслити ті проблеми, які залишаються не повністю вирішеними у цьому аспекті.

Важливе значення для забезпечення ефективної інтеграції дітей з особливими освітніми потребами у навчальне середовище має діагностика розвитку дітей, визначення їхніх потреб з метою подальшого розроблення шляхів корекційнорозвивальної роботи. Виявлення особливостей розвитку дитини передбачає такі основні якісні показники, що характеризують ї̈ діяльність: наявність і стійкість інтересу до діяльності; розуміння інструкції; самостійність виконання; характер діяльності (цілеспрямованість і активність); темп і динаміка діяльності; працездатність; сприймання допомоги та ін. До показників, що характеризують особливості пізнавальної сфери і психомоторної функції дитини, відносять: особливості уваги, сприймання, пам'яті, мислення, мовлення; особливості психомоторної сфери (стан тонусу, загальної моторики, дрібної моторики, зоровомоторної координації, моторна швидкість, пластичність, рухове наслідування, тактильний контакт); аналіз поведінки дитини.

У цьому сенсі Інститутом спеціальної педагогіки і психології імені Миколи Ярмаченка НАПН України створено вітчизняні конкурентноспроможні методики діагностики та розвитку таких дітей: зокрема, нові методики діагностики дітей $з$ аутизмом, на основі яких апробуються програми роботи щодо їхньої соціальної взаємодії; розроблено і впроваджено методику ABCDID: скринінг поведінки, спрямований на оцінку специфіки поведінкових проявів дітей та підлітків та ін.

Слід згадати, що у світовій практиці комплексна система допомоги родині, яка виховує дитину 
з особливими потребами, передбачає раннє виявлення, терапію та профілактику порушень розвитку у дитини. Підґрунтя цієї системи базується на функціональному підході (що в своїй основі містить Міжнародна класифікація функціонування, обмеження життєдіяльності та здоров'я дітей і підлітків), динамічних системних теоріях, біопсихосоціальних моделях інвалідності (нейропластічності, холістичного сприйняття людини), що орієнтуються на пріоритети сім'ї і потреби дитини.

3 огляду на це Інститутом розроблено концептуальну модель використання Міжнародної класифікації функціонування, обмеження життєдіяльності та здоров'я дітей і підлітків в освіті дітей з особливими потребами, програми з раннього втручання, спрямовані на надання допомоги дітям від 3 до 6 років. Важливо відзначити, що усі програми є профілактично-зорієнтованими, спрямованими на попередження й ранню абілітацію / реабілітацію розвитку дитини, покращення життєдіяльності родини, яка її виховує.

Наступною невід'ємною складовою супроводу $\epsilon$ психопрофілактика, завдання якої зорієнтовані на створення освітнього середовища для дітей з особливими освітніми потребами з опорою на предметно-просторові та організаційно-смислові ресурси. Предметно-просторові ресурси містять структурування простору та врахування важливих предметів для перетворення навчального середовища для дітей з особливими потребами, організаційно-смислові - структурування різних сфер життєдіяльності (навчання, побут, дозвілля); дозоване навантаження; візуальну підтримку; адаптацію навчальних підходів (використання навчальних завдань різного рівня складності; збільшення часу на виконання завдань; зміна темпу занять; чергування видів діяльності); адаптацію навчальних посібників, наочних та інших матеріалів, застосування додаткових способів подання матеріалу.

В Україні створюються відповідні організаційно-смислові ресурси для таких осіб у процесі навчання, зокрема Інститутом спеціальної педагогіки і психології імені Миколи Ярмаченка НАПН України розроблено критерії оцінювання знань, умінь і здібностей учнів з порушеннями інтелекту, Типові освітні програми для початкової ланки для таких дітей та програмно-методичне забезпечення дошкільної освіти, адаптовано підручники шрифтом Брайля та ін.
На окрему увагу заслуговує визначення теоретико-методологічних і методичних засад жестової мови та окреслення шляхів подальшого її вивчення не лише як засобу комунікації нечуючих та їх навчання, але й як навчальної дисципліни. Саме завдяки розробкам співробітників Інституту українську жестову мову вперше введено до навчального плану і як окрему дисципліну, і як засіб навчання.

Невіддільною технологією в системі супроводу є система корекційно-розвивальної роботи з «особливою» дитиною з опорою на базові структури ії психічної організації. У цьому контексті головним, на наше переконання, є продумана стратегія цієї роботи і послідовне її втілення на практиці. Йдеться про такі позиції, як: адаптація навчальних, корекційно-розвивальних програм, підручників до реальних можливостей дитини з орієнтацією на перспективу розвитку; послідовна робота фахівців з родиною як системою і активне залучення батьків до роботи з дитиною; налагодження взаємодії із зовнішніми організаціями і фахівцями задля дотримання принципу наступності освітнього процесу.

Втім, на нашу думку, ефективний освітній простір для дитини з особливими потребами не може будуватися за умови впровадження лише корекційно-розвивальної роботи, а має містити розуміння глибокого психологічного й соціальнопсихологічного контексту як самого освітнього процесу, так і всіх форм взаємодії у ньому. Відтак, у цьому контексті важливою $є$ технологія командної взаємодії учасників групи супроводу, визначення певного типу освітнього середовища та розроблення індивідуальної програми розвитку дитини.

Хотілося 6 відзначити, що на запит Міністерства соціальної політики співробітниками Інституту спеціальної педагогіки і психології імені Миколи Ярмаченка НАПН України було створено команду психолого-педагогічного супроводу і на підґрунті комплексної психолого-педагогічної оцінки дітей шкільного віку спеціальної школи-інтернату розроблені психологічні портрети дітей та зроблено висновки, пов'язані з інтерпретацією, поясненням, тлумаченням зібраної інформації, відтворенням загальної картини рівня розвитку дитини та реального рівня становлення її навчальної діяльності. Ці висновки містять узагальнену психологопедагогічну характеристику дитини та поради щодо її залучення до певного типу освітнього середовища. 
Комплексна психолого-педагогічна оцінка дітей шкільного віку проводилася протягом трьох місяців з чотириденним перебуванням психологів- та педагогів-науковців в освітній установі. Обстеженням охоплено 256 дітей.

Психолого-педагогічна оцінка містила:

- комплекс діагностичних процедур з метою повного орієнтування щодо суб'єкта вивчення, рівня розвитку психічної сфери дитини, сформованості навчальної діяльності. Обстеження передбачало цілеспрямоване і планомірне вивчення особистості дитини, співпрацю з педагогами та психологами освітньої установи відповідно до запропонованої програми і включало три основних етапи: збір інформації, обробку та систематизацію отриманих даних, конструювання висновків;

- аналіз отриманих даних за окремими блоками психічної сфери дитини (сприймання, уявлення, увага, пам'ять, мислення, пізнавальна активність, самоконтроль, самооцінка, спілкування, мова, емоційно-вольова сфера), визначення навчальних умінь і навичок;

- висновки про стан, тенденції розвитку суб'єкта вивчення;

- вибір діагностичного інструментарію (у процесі збору інформації, окрім визначених діагностичних методик, широко використовувалися такі дослідницькі методи, як спостереження, інтерв'ю, анкетування, колективна співбесіда, діагностичні ситуації, вивчення документації, експертна оцінка тощо);

- заключне обстеження (формулювання психолого-педагогічних висновків) та визначення напрямів освітньої траєкторії кожного учня;

- надання висновків, пов'язаних з інтерпретацією, поясненням, тлумаченням зібраної інформації, відтворенням загальної картини рівня розвитку дитини та реального рівня становлення ії навчальної діяльності.

На основі комплексної психолого-педагогічної оцінки стану розвитку дитини здійснено моніто- ринг динаміки розвитку і навчання дітей та надано рекомендації щодо залучення кожної дитини до певного типу освітнього середовища, визначено нагальні цілі розвитку кожної дитини і покрокове їх досягнення (табл. 1).

Частину цих напрацювань відображено у навчально-методичному посібнику «Організаційнометодичні засади діяльності інклюзивноресурсних центрів», який містить методики комплексного психолого-педагогічного супроводження дітей з особливими освітніми потребами, методичні рекомендації щодо надання корекційно-розвивальних послуг, рекомендації фахівцям та батькам, які виховують таких дітей й інше.

Наступною важливою складовою супроводу осіб з особливими освітніми потребами $є$ технологія самооцінки професійного розвитку фахівців, різноаспектність функцій і завдань якої передбачає розширення провадження освітньої діяльності у сфері післядипломної освіти для осіб з вищою освітою, визначення нових концептуальних основ професійного зростання педагогів, постійного оновлення напрямів, змісту і форм навчання відповідно до освітніх потреб осіб з особливими потребами.

у цьому контексті з 2012 р. і до цього часу Інститут спеціальної педагогіки і психології імені Миколи Ярмаченка НАПН України надає освітні послуги з підвищення кваліфікації науковопедагогічних і педагогічних працівників закладів освіти та установ, що реалізують державну політику у галузі освіти осіб з особливими потребами. Окреслено низку проблем, на розв'язання яких спрямована діяльність установи:

- організація навчального процесу відповідно до потреб економічного і соціального розвитку держави на основі впровадження результатів сучасних наукових досліджень, широкого використання вітчизняного та зарубіжного досвіду освітньої діяльності в сфері післядипломної освіти для осіб з вищою освітою;

Узагальнені висновки щодо залучення дітей до певного типу освітнього середовища

\begin{tabular}{|l|l|l|l|}
\hline $\begin{array}{l}\text { Можуть інтегруватися у зага- } \\
\text { льноосвітнє середовище }\end{array}$ & $\begin{array}{l}\text { Можуть інтегруватися у зага- } \\
\text { льноосвітнє середовище піс- } \\
\text { ля закінчення початкової } \\
\text { ланки освіти у спеціальних } \\
\text { закладах освіти }\end{array}$ & $\begin{array}{l}\text { Потребують навчання за спе- } \\
\text { ціальними навчальними про- } \\
\text { грамами у спеціальних закла- } \\
\text { дах освіти }\end{array}$ & $\begin{array}{l}\text { Потребують індивідуального } \\
\text { навчання (діти зі складними } \\
\text { порушеннями психофізичного } \\
\text { розвитку) }\end{array}$ \\
\hline 36 дітей & 35 дітей & 164 дитини & 21 дитина \\
\hline Усього обстежено: 256 дітей
\end{tabular}


- науково-методична підтримка в контексті деінституалізації, інклюзивного навчання, що передбачає організацію підвищення кваліфікації керівних, наукових, науково-педагогічних і педагогічних працівників закладів освіти та установ, що реалізують державну політику у галузі освіти осіб з особливими потребами з урахуванням соціально-економічного розвитку України;

- розширення професійного профілю осіб 3 вищою освітою та підвищення кваліфікації фахівців шляхом внесення інноваційних програм в межах спеціальностей «016 Спеціальна освіта» та «053 Психологія» з урахуванням потреб галузей науки в державі та регіонах, зокрема надання послуг здобувачам щодо проведення комплексної психолого-педагогічної оцінки розвитку дитини; щодо психолого-педагогічних, корекційнорозвивальних послуг дітям з особливими освітніми потребами та забезпечення їх системного кваліфікованого супроводу;

- визначення особливостей розвитку, навчання та виховання дітей з особливими освітніми потребами та ін.

Безперечно, означені та багато інших питань вже знаходяться у центрі уваги дослідників, управлінців і практиків. Втім, як на нашу думку, існують певні проблеми, які потребують нагального розв'язання, зокрема:

- розроблення методик і програм раннього виявлення і корекційного впливу на дітей з особливими потребами, що має ґрунтуватися на комплексній психолого-педагогічній оцінці розвитку дитини. Важливою при цьому є підготовка фахівців, які володіють міжнародно визнаними методиками;
- з метою ефективного запровадження механізмів раннього втручання, необхідним є створення відповідної нормативно-правової бази, де було б чітко прописано принципи раннього втручання;

- розроблення різних сертифікаційних програм, курсів для фахівців, створення шкіл для батьків, які виховують дітей з особливими освітніми потребами та інші.

Підводячи підсумки, хотілося 6 додати, що розв'язання окреслених завдань має бути будуватися на засадах дитиноцентризму й компетентнісного підходу, що є визначальними в інноваційних векторах розвитку освіти дітей з особливими потребами.

\section{СПИСОК ВИКОРИСТАНИХ ДЖЕРЕЛ}

Засенко, В.В., \& Прохоренко, Л.І. (2018). Нова українська школа - стратегія розвитку освіти дітей з особливими потребами. In N. Nyczkalo, J. Kunikowski, G. Wiezbicki (Eds), Nauka Edukacja Wychowanie i Praca (pp. 149-258). Warszawa-Siedlce.

Міністерство освіти і науки України (2016). Нова українська школа. Концептуальні засади реформування середньої школи. Взято 3 https://www.kmu.gov.ua/storage/app/ media/reforms/ukrainska-shkola-compressed.pdf.

План заходів з реалізації у 2019-2021 роках пілотного проекту «Створення системи надання послуги раннього втручання для забезпечення розвитку дитини, збереження її здоров'я та життя» (2019). Взято 3 https:// www.kmu.gov.ua/storage/app/uploads/public/5ce/ bc0/48c/5cebc048c18b8385719290.doc.

Прохоренко, Л.І. (2019). Освіта осіб з особливими потребами: науково-психологічний супровід. Педагогіка і психологія. Вісник НАПН України, (4), 25-34.

Указ Президента України «Про затвердження Національної стратегії у сфері прав людини» від 25 серпня 2015 р. № 501/2015. Взято $3 \mathrm{https://zakon.rada.gov.ua/laws/}$ show/501/2015

Zasenko, V., \& Prokhorenko, L. (2018). Educational Development Priorities for People with Special Needs in Ukraine. Education: Modern Discourses, (1), 161-167. https:// doi.org/10.32405/2617-3107-2018-1-15.

\section{SCIENTIFIC AND PSYCHOLOGICAL SUPPORT IN EDUCATION OF CHILDREN WITH SPECIAL NEEDS \\ Scientific report at the General Meeting of the National Academy of Educational Sciences of Ukraine, December 17, 2019}

\section{Lesya Prokhorenko}

DSc in Psychology, Deputy Director for Scientific and Experimental Work, Mykola Yarmachenko Institute of Special Pedagogy and Psychology of the National Academy of Educational Sciences of Ukraine, Kyiv, Ukraine

Abstract. The author outlines important issues of education of children with special educational needs, in particular, focuses on the technologies of social, psychological and pedagogical support of children with special needs, in which the identification of features of the personal development of the child and its social formation in school conditions are of primary importance. It is substantiated that changing stereotypes in understanding the problems of education and upbringing of children with special needs should be based on new approaches that focus not on personality disorders, but which underpin personal orientation, educational competences, creation of appropriate conditions for equal opportunities for children and young people education, variability of training according to the abilities and individual abilities of such persons, etc. Taking into account the main tendencies for changes in the education system of children with special educational needs, the areas of activity that need special attention are outlined, the leading ones being scientific and methodological support of education of persons with special needs and psychological and pedagogical support of such persons in the process of learning, socialization, life.

Keywords: scientific and psychological support; education of children with special needs; early intervention; inclusive education.

Дата публікації: 23 грудня 2019 р. 